\title{
SELECTIVE DISTRIBUTION OF TRADEMARKED PRODUCTS AND RESTRICTIONS OF ONLINE SALES ${ }^{*}$
}

\author{
Igor Materljan, M.Sc, Legal Officer \\ European Commission, DG EUROSTAT \\ 5, rue Alphonse Weicker - bâtim. Joseph Bech, 2721 Luxembourg, \\ Luxembourg \\ igor.materljan@gmail.com
}

\author{
Gordana Materljan, LL.M, Legal Officer \\ European Commission, Publications Office \\ 2, Rue Mercier, 2985 Luxembourg, Luxembourg \\ goga1981@gmail.com
}

\begin{abstract}
The paper analyses recent decisions delivered by the Court of Justice of the European Union (CJEU) addressing the contemporary challenges facing selective distribution systems. It addresses the legality of restrictions of online sales imposed on distributors. In Coty, a case concerning the selective distribution of luxury products, the CJEU ruled that the restriction of using third-party platforms was compatible with competition law. In order to reach that conclusion, it relied on its trademark jurisprudence. In this regard, several issues emerge: the link between trademark and competition law and the applicability of the ruling on non-luxury products. Coty presents a departure from the CJEU's earlier judgement delivered in Pierre Fabre and different national authorities interpreted it differently. It seems that the debate over these issues is far from over. The purpose of this paper is to contribute to the discussion trying to reconcile diverging decisions. It is principally based on a case-law analysis, providing critical assessment of the decisions under scrutiny (i.e. CJEU's case law and the divergent decisions delivered by different national authorities). The study is supported by an analysis of scientific legal and economic papers concerning selective distribution and e-commerce. The research shows that the outcome of the cases depends largely on the concrete factual circumstances. However, certain
\end{abstract}

The content of this paper does not reflect the official opinion of the European Union. The paper is written on a strictly personal basis and have not been endorsed by any service of the European Commission. The authors are in no way involved in ongoing review of the Vertical Block Exemption Regulation (Commission Regulation (EU) No 330/2010 of 20 April 2010 on the application of Article 101(3) of the Treaty on the Functioning of the European Union to categories of vertical agreements and concerted practices). Responsibility for the information and views expressed therein lies entirely with the authors. The authors would like to thank the anonymous reviewers for all of their constructive and insightful comments and suggestions. 
points appear to be relevant for all the analysed cases, i.e. the applicability of Coty to non-luxury products and the extent of restrictions that triggers the breach of competition law.

Keywords: Selective distribution, competition law, trademark law, exhaustion of trademark rights, luxury products, non-luxury products

\section{INTRODUCTION}

Generally, there are three distribution strategies: selective, intensive and exclusive. Selective distribution is a system established by a vertical agreement, whose goal is twofold: first, to limit the number of authorised distributors (not to eliminate all competition altogether), and second, to prohibit sales to non-authorised distributors. ${ }^{1}$ The authorised distributors are allowed to sell differentiated products in the same market segment, i.e. products that are in inter-brand competition. Thus, selective distribution leaves only final consumers and authorised dealers as possible buyers.

Selective distribution is most appropriate for the sale of branded goods ${ }^{2}$ on a large scale. Suppliers supplying luxury, complex or technical products wish to limit the resale of their products to "approved dealers only". They want to sell their products through distribution channels that possess at least a minimum of technical expertise or that are consistent with their branded image. In order to select the distributor, they may use different criteria. Regardless of the selection criteria used, the suppliers' intent is always to prevent approved dealers from selling to non-approved dealers, since the latter could jeopardise their distribution strategy.

The selective distribution system plays a very important role in the way customers come into contact with the goods of the brand in question. ${ }^{3}$ That experience is, among others, very important for customers' perception of the products and for the image of the brand. ${ }^{4}$ This is why the selective distribution system is seen as an

1 The notion of selective distribution is defined in the Commission Regulation (EU) No 330/2010 of 20 April 2010 on the application of Article 101(3) of the Treaty on the Functioning of the European Union to categories of vertical agreements and concerted practices [2010] OJ L 102/1. It means a distribution system where the supplier undertakes to sell the contract goods or services, either directly or indirectly, only to distributors selected on the basis of specified criteria and where these distributors undertake not to sell such goods or services to unauthorised distributors within the territory reserved by the supplier to operate that system. Article 1(1)(e) of Regulation 330/2010

2 Guidelines on Vertical Restraints [2010] OJ C 130/1, para 174

3 Vogel, L.; Vogel, J., Traité de droit économique : Tome 2 - Droit de la distribution, Bruylant, Bruxelles, 2017, pp. 431-438

4 Kato T.; Tsuda K., A Management Method of the Corporate Brand Image Based on Customers' Perception, Procedia Computer Science, Vol. 126, 2018, pp. 1368-1377; Koll O.; von Wallpach S., One brand perception? Or many?, Journal of Product \& Brand Management, Vol. 18, Number 5, 2009, pp. 338-345 
efficient tool to protect the brand image. ${ }^{5}$ Firstly, the selection of distributors and the reduction of retail space allow maintaining the luxury image of some products, even when they are highly commercialised. Secondly, the system allows the technical products to be sold by competent sellers providing an after-sale service.

Even though it seems that the operator of the distribution system decides who will sell his products and how, contracts between a manufacturer and distributor are much more complicated. The parties of the contract usually agree on the restraints of price and to whom the retailer may sell the products. ${ }^{6}$ The vertical agreement between the operator and the distributor creates a closed relationship between them. It is for that reason that the agreement falls under the strict regulation of competition law. ${ }^{7}$

A selective distribution system may have pro- and anti-competitive effects. It can be economically beneficial, in the sense that it can prevent free-riding, helping creating a brand image for luxury, complex and technical products and thus prompts interbrand competition. ${ }^{8}$ However, that strategy tends to exclude discounters and therefore allows the maintenance of higher prices, which in turn reduces intra-brand competition. ${ }^{9}$ The competent competition regulators weigh these effects when deciding whether the vertical agreement is compatible with competition law. ${ }^{10}$

There is a special relationship between trademarks and selective distribution systems. ${ }^{11}$ Under certain conditions, the presence of a trademark in a vertical agreement may prevent the application of competition rules. ${ }^{12}$ From that perspective, trademarks can be considered as tools for the protection of selective distribution

$5 \quad$ Paseczki L; Rózsavölgyi M., Trademarks and selective distribution: The protection of brand image and identity, ECTA, 2018, [http://www.ecta.org/uploads/events-documents/article_PL_RM.pdf] Accessed 15.03.2018

6 Winter R. A., Pierre Fabre, Coty and Restrictions on Internet Sales: An Economist's Perspective, Journal of European Competition Law \& Practice, Vol. 9, No. 3, 2018, pp. 183-187

7 Case 56/65 Société Technique Minière [1966] EU:C:1966:38; joined cases 56/64 and 58/64 Consten and Grundig v Commission [1966] EU:C:1966:41; case T-99/04 AC Treuhand v Commission [2008] EU:T:2008:256; case C-306/96 Javico [1998] EU:C:1998:173

$8 \quad$ Bailey D.; John L. E. (eds.), Bellamy \& Child: European Union Law of Competition (8th Edition), Oxford University Press, Oxford, 2018, pp. 495-496

9 Guidelines on Vertical Restraints, para 178

10 Reisinger M., Asics vs Coty: Competitive effects of selective distribution systems in light of diverging court decisions, CPI's Europe Column, 2018, pp. 1-5

11 For a detailed discussion on the trademark functions in the context of selective distribution systems see Kunda I.; Butorac Malnar V., Internet Distribution of Luxury Products: Is There a Deluxe Version of EU Competition Law?, Zbornik Pravnog fakulteta Sveučilišta u Rijeci, Vol. 39, No. 4, Posebni broj, 2018, pp. 1751-1774

12 Tuytschaever F.; Wijckmans F., Vertical Agreements in EU Competition Law (3rd Edition), Oxford Competition Law, Oxford, 2018, paras 4.15 and 4.16 
systems. ${ }^{13}$ On the other hand, rights conferred by a trademark are exhausted in relation to goods which have been put on the market in the European Economic Area under the trademark in question, whether by the proprietor itself or with its consent. ${ }^{14}$ This allows for the trademarked products to be sold by parallel networks, outside the distribution system put in place by the manufacturer.

The use of algorithms has created new challenges in the field of competition law. New distribution formats emerged. Digital marketplaces (like Amazon or eBay) make it easier for retailers to access customers in more than one Member State. Even though companies compete on parameters such as quality and innovation ${ }^{15}$, the use of third party online platforms significantly affects the distribution and pricing strategies of manufacturers and retailers. ${ }^{16}$ Many industries successfully tackled the change by engaging in dual and multi-channel distribution. Manufactures started selling goods both through distributors and their own stores, online, brick-and-mortar and/or specialist stores etc. ${ }^{17}$ Traditional online sellers started opening brick-andmortar stores, price comparison websites started to offer direct-purchase options and online retailers started to offer sales opportunities for other retailers. ${ }^{18}$ These new distribution formats have been scrutinized by national and EU competition regulators.

This paper addresses several issues regarding restrictions in online sales and the use of third-party platforms in EU law and its implementation on national level. The first part is dedicated to the CJEU's most important decisions with regard to offline selective distribution systems. Special focus is on Metro cases ${ }^{19}$, Leclerc cases $^{20}$ and

13 Vogel; Vogel, op. cit., note 3., pp. 529-533

14 For a general overview of exhaustion of rights conferred by a trademark see Kunda I.; Materljan I., The EEA "Grey Market" in Trademarked Products: How Many Shades of Grey?, working paper presented at the INTA Annual Meeting, Trademark Scholarship Symposium 2017, [http://en.croatiamergers.eu/ wp-content/uploads/2017/12/Kunda_Materljan-INTA_Working_Paper.pdf] Accessed 15.04.2019

15 Colomo P.I.; De Stefano G., The Challenge of Digital Markets: First, Let Us Not Forget the Lessons Learnt Over the Years, Journal of European Competition Law \& Practice, Vol. 9, Issue 8, 1 2018, pp 485-486

16 Report from the Commission to the Council and the European Parliament, Final report on the E-commerce Sector Inquiry, COM(2017) 229 final, 10 May 2017, [http://ec.europa.eu/competition/antitrust/sector_inquiry_final_report_en.pdf] Accessed 15.03.2019

17 Arnold R.; Norman N.; Schmierer D., Resale Price Maintenance and Dual Distribution, Distribution and Franchising Committee: ABA Section of Antitrust Law, March 2016, [https://www.cornerstone. com/Publications/Articles/Resale-Maintenance-and-Dual-Distribution] Accessed 15.04.2019

18 Kuhn T.; Rust M., Who'd have guessed: Coty did not end the debate!, Lexology, 28 February 2019, [https://www. lexology.com/library/detail.aspx?g=9bd96871-695e-4d2f-9106-cf64a65c955a] Accessed 15.03.2018

19 Case 26-76 Metro SB-Großmärkte GmbH \& Co. KG v Commission of the European Communities [1977] EU:C:1977:167; case 75/84 Metro SB-Großmärkte GmbH \& Co. KG v Commission of the European Communities [1986] EU:C:1986:399

20 Case T-19/92 Groupement d'achat Edouard Leclerc v Commission of the European Communities [1996] EU:T:1996:190; case T-88/92 Groupement d'achat Édouard Leclerc v Commission of the European Communities [1996] EU:T:1996:192 
$\operatorname{Copad}^{21}$. The second part addresses the issues concerning restrictions in online sales developed by the CJEU, in particular in Pierre Fabre $e^{22}$ and Coty ${ }^{23}$. The third part scrutinizes two decisions given by two different national competition regulators, i.e. the German Bundeskartellamt and the French Autorité de la concurrence. In relatively similar cases national authorities ruled that the selective distribution system established by the shoe manufacturer Asics (in the first case ${ }^{24}$, decision confirmed by the German Bundesgerichtshof ${ }^{25}$ ) and the chainsaw manufacturer Stihl (in the second case $^{26}$ ) violates competition law with regard to online sales. By contrast, in the Coty case, the CJEU ruled that the selective distribution system operated by a beauty products manufacturer is compatible with competition law. The fourth part analyses the implications of the mentioned decisions. In the two national cases, the national authorities gave more weight to the anticompetitive effects, while the CJEU gave priority to the procompetitive ones. In order to reconcile these diverging decisions, the paper focuses on the points emphasized by the CJEU, i.e. the brand image and the aura of luxury that Coty's products convey and the extent of the prohibition imposed on the distributors. It appears from the analysis that the debate is far from over. The paper concludes with final remarks.

\section{LEGITIMACY OF SELECTIVE DISTRIBUTION SYSTEMS IN EU LAW}

\subsection{Basic principles and general conditions}

Article 101(1) of the Treaty on the Functioning of the European Union (TFEU) ${ }^{27}$ prohibits agreements between undertakings which may affect trade between Member States and which have as their object or effect the prevention, restriction or distortion of competition within the internal market. Restrictions of competition

21 Case C-59/08 Copad SA v Christian Dior couture SA, Vincent Gladel and Société industrielle lingerie (SIL) [2019] EU:C:2009:260

22 Case C-439/09 Pierre Fabre Dermo-Cosmétique SAS v Président de l'Autorité de la concurrence and Ministre de l'Économie, de l'Industrie et de l'Emploi [2011 EU:C:2011:649

23 Case C-230/16 Coty Germany GmbH v Parfümerie Akzente GmbH [2017] EU:C:2017:941

24 Bundeskartellamt, Decision n. B2-98/11 of 26 August 2015, [https://www.bundeskartellamt.de/ SharedDocs/Entscheidung/EN/Fallberichte/Kartellverbot/2016/B2-98-11.pdf?__blob=publicationFile\&v=2] Accessed 15.03.2019

25 Bundesgerichtshof, Beschluss KVZ 41/17 vom 12. Dezember 2017 in der Kartellverwaltungssache, [http://juris.bundesgerichtshof.de/cgi-bin/rechtsprechung/document.py?Gericht=bgh\&Art=en \&Datum=Aktuell\&Sort=12288\&nr=80673\&pos=25\&anz=515] Accessed 15.03.2019

26 Autorité de la concurrence, Décision n ${ }^{\circ} 18-\mathrm{D}-23$ du 24 octobre 2018 relative à des pratiques mises en œuvre dans le secteur de la distribution de matériel de motoculture, [http://www.autoritedelaconcurrence.fr/pdf/avis/18d23.pdf] Accessed 15.03.2019

27 Consolidated version of the Treaty on the Functioning of the European Union [2016] OJ C 202/1 
"by object" are those that by their very nature have the potential to restrict competition, while restrictions of competition "by effect" are those that have likely anti-competitive effects. In the case of restrictions of competition by effect there is no presumption of anti-competitive effects. For an agreement to be restrictive by effect it must affect actual or potential competition to such an extent that on the relevant market negative effects on prices, output, innovation or the variety or quality of goods and services can be expected with a reasonable degree of probability. ${ }^{28}$

In order to determine whether an agreement involves a restriction of competition "by object" (also called "hardcore restriction"), a number of elements must be taken into consideration, e.g. the agreement's content, its objectives and the economic and legal context of which it forms a part. ${ }^{29} \mathrm{With}$ respect to agreements between non-competitors (vertical agreements), the category of restrictions by object includes, in particular, the fixing of (minimum) resale prices and restrictions which limit sales into particular territories or to particular customer groups. Vertical agreements which have as their object the restriction of competition are prohibited under Article 101(1) TFEU and no actual anti-competitive effects need to be demonstrated. ${ }^{30}$ However, the parties may demonstrate that the conditions set out in Article 101(3) TFEU are satisfied if they want the agreement to be considered compatible with the internal market.

Further on, a restriction "by object" may be compatible with Article 101 TFEU when it is objectively necessary for the existence of an agreement of a particular type or nature, or for the protection of a legitimate goal. ${ }^{31}$ In principle, a restriction on a buyer as to where (the territory) or to whom (the customers) he can sell the contract products, actively and/or passively, is a restriction "by object". Finally, the European Commission provided for a safe harbour by means of Regulation 330/2010. This concerns agreements between undertakings which are considered to have non-appreciable effects on competition, in cases when market shares of

28 Communication from the Commission, Notice, Guidelines on the application of Article 81(3) of the Treaty (2004/C 101/08) [2004] OJ C 101/97

29 European Commission, Guidance on restrictions of competition "by object" for the purpose of defining which agreements may benefit from the De Minimis Notice, SWD(2014) 198 final, 25 June 2014, [http://ec.europa.eu/competition/antitrust/legislation/de_minimis_notice_annex.pdf] Accessed 15.03.2019

30 Bailey; John, op. cit., note 8, p. 497

31 Guidelines on Vertical Restraints, paras 18, 60, 61 and 62 
the undertakings parties to the agreements do not exceed the market share thresholds $^{32}$ and when the object of the agreements is not restricting competition. ${ }^{33}$

In regard to selective distribution systems, prohibiting authorized distributors, within the territory where the selective distribution system operates, from selling to distributors who are not members of the selective distribution system is not considered a restriction "by object". ${ }^{34}$

The CJEU established the basic principles for assessing selective distribution systems in the Metro cases decided in the 1970s and the 1980s. ${ }^{35}$ The Metro cases concerned a "cash and carry" outlet which had been refused supplies of SABA electrical products, limited to approved dealers. The selective criteria used by the supplier contained qualitative requirements (i.e. that the dealer was specialised in electrical products, had adequate premises and employed staff, and an obligation for the dealer to provide after sale service), as well as quantitative requirements (i.e. the dealer had to be prepared to enter in a six-month forward supply contract and to maintain specified stock levels). ${ }^{36}$

According to the CJEU, selective distribution systems based solely on objective quantitative criteria do not fall within Article 101(1) TFEU. In fact, in such systems price competition is not generally emphasized either as an exclusive or as a principal factor. The CJEU stated in this regard that "although price competition is so important that it can never be eliminated it does not constitute the only effective form of competition or that to which absolute priority must in all circumstances be accorded." ${ }^{37}$ Selective distribution systems based solely on objective quantitative criteria are thus considered to achieve a result which enhances com-

32 Article 3 of Regulation 330/2010

33 Article 4 of Regulation 330/2010

34 Article 4(b)(iii) of Regulation 330/2010. See also European Commission, Guidance on restrictions of competition "by object" for the purpose of defining which agreements may benefit from the De Minimis Notice, SWD(2014) 198 final, 25 June 2014, [http://ec.europa.eu/competition/antitrust/ legislation/de_minimis_notice_annex.pdf] Accessed 15.03.2019

35 Case 26-76 Metro SB-Großmärkte GmbH \& Co. KG v Commission of the European Communities [1977] EU:C:1977:167; case 75/84 Metro SB-Großmärkte GmbH \& Co. KG v Commission of the European Communities [1986] EU:C:1986:399; joined cases 25 and 26/84 Ford - Werke AG and Ford of Europe Inc. v Commission of the European Communities [1985] EU:C:1985:340; case 107/82 Allgemeine Elektrizitäts-Gesellschaft AEG-Telefunken AG v Commission of the European Communities [1986] EU:C:1983:293

36 Case 26-76 Metro SB-Großmärkte GmbH \& Co. KG v Commission of the European Communities [1977] EU:C:1977:167, paras 26-36

37 Ibid., para 21 
petition and which counterbalances the reduction in competition, particularly as regards price, inherent in such systems. ${ }^{38}$

There is an exception to the abovementioned general rule. The CJEU clarified that although "simple" selective distribution systems are capable of constituting an aspect of competition compatible with Article 101 (1) TFEU, "there may nevertheless be a restriction or elimination of competition where the existence of a certain number of such systems does not leave any room for other forms of distribution based on a different type of competition policy or results in a rigidity in price structure which is not counterbalanced by other aspects of competition between products of the same brand and by the existence of effective competition between different brands." ${ }^{39}$ In other words, a distribution system may fall under Article 101(1) TFEU when the cumulative effect of such systems precludes other methods of distribution from competing in the relevant market.

The CJEU further developed the principles established in the Metro cases during the 1980s and the 1990s. Generally, the selective distribution system will not fall within Article 101(1) TFEU if these four conditions are met: 1) resellers are chosen on the basis of objective criteria of a qualitative nature (e.g. the supplier may ask for technically qualified stuff, suitable premises, the ability to display the products and to provide after-sales services etc.), 2) criteria are laid down uniformly for all potential resellers and are not applied in a discriminatory manner, 3) the characteristics of the product in question necessitate such a network in order to preserve its quality and ensure its proper use, and 4) the laid down criteria do not go beyond what is necessary to attain this object. These criteria were further repeated by the CJEU in almost every decision concerning selective distribution systems. ${ }^{40}$ Thus, if these requirements are fulfilled, the restriction of competition is presumed to be lawful.

Concerning the third condition, the nature of the product in question must necessitate a selective distribution system, in the sense that such a system must constitute a legitimate requirement, having regard to the nature of the product concerned, to preserve its quality and ensure its proper use. ${ }^{41}$ Article 101(1) TFEU does not

\footnotetext{
38 Case 107/82 Allgemeine Elektrizitäts-Gesellschaft AEG-Telefunken AG v Commission of the European Communities [1986] EU:C:1983:293 paras 34 and 37; case C-230/16 Coty Germany GmbH v Parfümerie Akzente GmbH, Opinion of advocate General Wahl [2017] EU:C:2017:603, para 45

39 Case 75/84 Metro SB-Großmärkte GmbH \& Co. KG v Commission of the European Communities [1986] EU:C:1986:399, para 40

40 See e.g. Case C-230/16 Coty Germany GmbH v Parfümerie Akzente GmbH [2017] EU:C:2017:941, para 24.

41 Commission's Guidelines on Vertical Restraints [2010] OJ C 130/1
} 
apply only if objective technical (qualitative) requirements are reasonably necessary for the proper sale of that product (in order to preserve its quality and ensure its proper use). ${ }^{42}$ It is not easy to determine whether the product justifies the use of a selective distribution system in a particular case. ${ }^{43}$ In fact, there are many examples where objective technical requirements were considered to be justified, i.e. in respect to cameras ${ }^{44}$, hi-fi products ${ }^{45}$ and quality watches ${ }^{46}$. On the other hand, there are examples where the same requirements were not considered to justify the selective distribution system, e.g. law-quality watches ${ }^{47}$, tobacco products ${ }^{48}$ and products whose quality is regulated by public law. ${ }^{49}$

\subsection{Luxury products: the Leclerc cases}

Basic principles concerning the legality of selective distribution systems established for luxurious and prestigious products were developed by the Court of First Instance's Leclerc cases in the 1990 s. $^{50}$ They concerned a selective distribution system for luxury cosmetics, challenged by Galec, a purchasing association responsible for supplying the Leclerc group retail outlets (primarily supermarkets and hypermarkets). In these cases, the systems for distribution of cosmetics products established by Yves Saint Laurent and Givenchy detailed the criteria for the location, aesthetic and functional qualities of the outlets admitted to the network.

The Court of First Instance held that the luxury image of these products was very important to consumers. It considered that it was in the interests of consumers seeking to purchase luxury cosmetics that the luxury image of such products is not tarnished,

42 Case 107/82 Allgemeine Elektrizitäts-Gesellschaft AEG-Telefunken AG v Commission of the European Communities [1986] EU:C:1983:293, para 33; case 31/80 NV L'Oréal and SA L'Oréal v PVBA “De Nieuwe AMCK” [1980] EU:C:1980:289, para 16

43 Guidelines on Vertical Restraints, paras 175 and 184-185

44 Commission Decision of 30 Juin 1970 relating to a proceeding pursuant to Article 81 of the EC Treaty and Article 53 of the EEA Agreement (IV/24055 - Kodak) (70/332/CEE)

45 Case 210/81 Oswald Schmidt, trading as Demo-Studio Schmidt, v Commission of the European Communities [1983] EU:C:1983:277

46 Case C-376/92 Metro SB-Großmärkte GmbH \& Co. KG v Cartier SA [1994] EU:C:1994:5

47 Case 31/85 ETA Fabriques d'Ébauches v SA DK Investment and others [1985] EU:C:1985:494

48 Joined Cases 209 to 215 and 218/78 Heintz van Landewyck SARL and Others v Commission of the European Communities [1980] EU:C:1980:248

49 Case 31/80 NV L'Oréal and SA L'Oréal v PVBA “De Nieuwe AMCK” [1980] EU:C:1980:289

50 Case T-19/92 Groupement d'achat Edouard Leclerc v Commission of the European Communities [1996] EU:T:1996:190; case T-88/92 Groupement d'achat Édouard Leclerc v Commission of the European Communities [1996] EU:T:1996:192 
as they would otherwise no longer be regarded as luxury products. ${ }^{51}$ Therefore, the nature of these products encompassed to a lesser extent the material quality of the product, and to a greater extent their "aura of luxury". That aura is essential in that it enables consumers to distinguish them from similar goods and, therefore, an impairment to that aura of luxury is likely to affect the actual quality of those goods. ${ }^{52}$

It stated that the fact that the products are sold through selective distribution systems which seek to ensure that they are presented in retail outlets in an enhancing manner also contributes to that luxury image and thus to the preservation of one of the main characteristics of the products which consumers seek to purchase. Generalised non-controlled distribution would disable the supplier of ensuring that its products were sold in appropriate conditions, would entail the risk of deterioration in product presentation in retail outlets and thus could harm the "luxury image" that is the very character of the product. $^{53}$

In order to counterbalance the restriction on competition inherent in selective distribution, the systems had to be open to all retailers who could present the products in an appropriate setting. The Court of First Instance stated that the criteria which seek only to ensure that products are presented in an enhancing manner pursue an objective which improves competition by preserving that luxury image and thus counterbalances the restriction of competition inherent in selective distribution systems. ${ }^{54}$

Commentators welcomed the decisions pointing out the need for clarification of the conditions for the assessment of the legality of selective distribution systems. ${ }^{55} \mathrm{How}$ ever, an analysis showed that the European Commission did not consistently apply in its decisions the criteria established by the Court of First Instance. ${ }^{56}$ It could be

51 Case T-19/92 Groupement d'achat Edouard Leclerc v Commission of the European Communities [1996] EU:T:1996:190, paras 119 and 120; case T-88/92 Groupement d'achat Édouard Leclerc v Commission of the European Communities [1996] EU:T:1996:192, paras 113 and 114

52 Case T-19/92 Groupement d'achat Edouard Leclerc v Commission of the European Communities [1996] EU:T:1996:190, paras 114-123; case T-88/92 Groupement d'achat Édouard Leclerc v Commission of the European Communities [1996] EU:T:1996:192, paras 108-117

53 Case T-19/92 Groupement d'achat Edouard Leclerc v Commission of the European Communities [1996] EU:T:1996:190, para 120; case T-88/92 Groupement d'achat Édouard Leclerc v Commission of the European Communities [1996] EU:T:1996:192, para 114

54 Case T-19/92 Groupement d'achat Edouard Leclerc v Commission of the European Communities [1996] EU:T:1996:190, para 119; case T-88/92 Groupement d'achat Édouard Leclerc v Commission of the European Communities [1996] EU:T:1996:192, para 113

55 Bretagne-Jaeger D., La distribution sélective des parfums de luxe consacrée à Luxembourg, Gazette du Palais, No. 159-161, 1997, pp. 11-14

56 Fort A., Règles et pratiques communautaires en matière de distribution sélective des produits de luxe dans l'Union européenne, L'Observateur de Bruxelles, No. 28, 1998. pp. 18-20 
argued that the "aura of luxury" is difficult to establish. The Leclerc judgements are based on the assumption that the marketing conditions are set in the interest of the consumers. Some commentators criticized such approach stating that the interest of consumers is not an appropriate criterion for assessing the legality of a selective distribution systems since it is highly subjective and cannot provide a reliable basis for the selection of the distribution system appropriate for a certain type of product. ${ }^{57}$ The EU authorities did not clearly address the question of diversifications in the treatment of luxury goods. This question is still awaiting an answer.

\subsection{Trademark exhaustion: the Copad case}

$\operatorname{Copad}^{8}{ }^{8}$ concerned a selective distribution system set up by the fashion branch of Dior company. In order to protect the prestige of its brand the supplier prohibited sales to discount stores, mail order companies and door-to-door sale companies. The selective distribution system was based on a trademark licensing agreement. According to that agreement, the supplier had licensed its trademark for the manufacture and distribution of its luxury products (underwear bearing the Christian Dior trademark) to SIL, a lingerie producer. The dispute arose after SIL had sold lingerie carrying the Dior trademark outside the selective distribution system, i.e. to Copad, a discount store. By selling Dior's trademarked products to Copad, SIL had breached the conditions established in the licencing agreement. ${ }^{59}$

The case is interesting for many reasons, inter alia, because Dior's primary concern was not the action against SIL (which was facing economic difficulties), but the enforcement of its trademark rights directly against Copad. Dior claimed that its trademark rights can be applied directly against the third party, and that therefore any further distribution of its trademarked goods is prohibited.

The action was based on the Trademark Directive $e^{60}$, in particular on its dispositions concerning licencing ${ }^{61}$ and exhaustion of the rights conferred by a trademark $^{62}$. According to the said dispositions, the trademark holder may license his

57 Art J. Y.; Van Liedekerke D., Developments in Ec Competition Law in 1996 - an Overview, Common Market Law Review, Vol. 34, Issue 4, pp. 895-956

58 Case C-59/08 Copad SA v Christian Dior couture SA, Vincent Gladel and Société industrielle lingerie (SIL) [2019] EU:C:2009:260

59 Ibid., paras 7-11

60 The act applicable to the case was the First Council Directive 89/104/EEC of 21 December 1988 to approximate the laws of the Member States relating to trade marks [1989] OJ L 40/1, now replaced by the Directive (EU) 2015/2436 of the European Parliament and of the Council of 16 December 2015 to approximate the laws of the Member States relating to trade marks [2015] OJ L 336/1)

61 Article 25 of Directive 2015/2436

62 Article 15 of Directive 2015/2436 
trademark for some or all of the goods for which it is registered. In addition, it has a remedy in case of breach of the license agreement; it can enforce the exclusive right to prevent others from using its trademark in the course of trade. ${ }^{63}$ This remedy is only available for specific types of breaches of the license agreement, inter alia, if the licensee violates a provision of the licensing agreement relating to the quality of the goods. ${ }^{64}$

The question referred to the CJEU was whether SIL's sale of Dior's trademarked goods outside the selective distribution system to Copad was a type of breach which enables the application of the trademark rights against third parties. The CJEU ruled that the breach in question was not a "simple" breach of licence agreement and that in fact the quality of goods manufactured is brought into question.

The CJEU stated that since luxury goods are high-class goods, the aura of luxury emanating from them is essential in that it enables consumers from distinguishing them from similar goods ${ }^{65}$ It held that an impairment of that aura of luxury is likely to affect the actual quality of those goods ${ }^{66}$ and that the conditions set up by the selective distribution system can, in themselves, preserve the quality and the proper use of such products. ${ }^{67}$ It concluded that the breach of licence agreement in question could damage the aura of luxury of the goods so as to affect the quality of the goods. ${ }^{68}$

The application of Dior's trademark rights against the third party, Copad, was made in two steps. First, since that violation constituted one of the violations enumerated in the Trademark Directive ${ }^{69}$, the CJEU determined that Dior could invoke its trademark right against its licensee SIL. The second step concerned the establishment of the link between the dispositions establishing the list of "special" breaches of licence agreement and the exhaustion of the rights conferred by a trademark. ${ }^{70}$

According to the exhaustion rule established by the Trademark Directive, once the trademarked goods have been placed on the market, the rights of the trademark owners are considered to be exhausted, provided that the goods have been mar-

\footnotetext{
63 Article 10 of Directive 2015/2436

64 The short list is contained in Article 25(2) of Directive 2015/2436

65 Case C-59/08 Copad SA v Christian Dior couture SA, Vincent Gladel and Société industrielle lingerie (SIL) [2019] EU:C:2009:260, para 24

66 Ibid., para 26

67 Ibid., para 28

68 Ibid., para 30

69 Article 25(2) of Directive 2015/2436

70 I.e. between Article 25(2) and Article 15(1) Directive 2015/2436
} 
keted with the trademark owners' consent. The consent-condition is essential in this case.

The CJEU's argumentation consists in holding that the trademarked goods put on the market by a licensee while breaching the licencing agreement were marketed without the consent of the trademark owner. The trademark owner was assumed not to have exhausted its trademark rights, because the mentioned consent-condition was not fulfilled. Therefore, it could invoke its trademark rights to prohibit a third party outside the selective distribution system to use it in the course of trade. ${ }^{71}$

Concerning the application of trademark rights outside the distribution system, the CJEU's line of argument was not always clear. In fact, in Peak Holding it held that contractual restrictions barring exhaustion could only affect the relationship between the parties to the contract. ${ }^{72}$ In the contrary, in Coty Prestige $v$ Simex it held that contractual restrictions may be effective only if externalized, i.e. visible for third parties. ${ }^{73}$

The approach developed in Copad was not applied in Pierre Faber, but was applied in Coty. Both cases will be examined in the next chapters.

\section{SELECTIVE DISTRIBUTION SYSTEMS AND ONLINE RESELLERS IN EU LAW}

\subsection{Ban of third-party platforms: the Pierre Fabre case}

Concerning brick-and-mortar channels of distribution, it is clear from the case law of the CJEU that the supplier may require distributors to maintain a luxury setting for its products.

In Pierre Fabre Th $^{74}$ the CJEU was confronted with the question concerning cases in which an authorised distributor wishes to sell the goods both in a brick-and-mortar store and via the internet. The manufacturer of cosmetics and other personal care products operated in the French and European markets through several subsidiaries. Even though the majority of products were not classified as medicines, distribution contracts provided that sales must be made exclusively in a physical space and in the

71 Case C-59/08 Copad SA v Christian Dior couture SA, Vincent Gladel and Société industrielle lingerie (SIL) [2019] EU:C:2009:260, para 51

72 Case C-16/03 Peak Holding AB v Axolin-Elinor AB (formerly Handelskompaniet Factory Outlet i Löddeköpinge AB) [2004] EU:C:2004:759

73 Case C-127/09 Coty Prestige Lancaster Group GmbH v Simex Trading AG [2010] EU:C:2010:313

74 Case C-439/09 Pierre Fabre Dermo-Cosmétique SAS v Président de l'Autorité de la concurrence and Ministre de l'Économie, de l'Industrie et de l'Emploi [2011 EU:C:2011:649 
constant presence of a pharmacist. This provision de facto excluded the possibility of selling the products on line. In 2008, the French Competition Authority held that those distribution agreements were contrary to competition law. The decision was challenged before the Cour d'appel de Paris (Paris Appeal Court), which requested a preliminary ruling on whether a general and absolute ban on internet selling amounts to a restriction of competition "by object", and whether such an agreement may benefit from a block ${ }^{75}$ or an individual exemption ${ }^{76}$.

The Commission's Guidelines on Vertical Restraints state that the internet is a powerful tool to reach customers, better than more traditional sales methods, and that every distributor must be allowed to use it. The use of a website is considered a form of passive selling and the overall sales made over the internet cannot be restricted. However, the supplier may require that the distributor sells at least a certain absolute amount (in value or volume) of the products offline to ensure an efficient operation of its brick-and-mortar store (physical point of sales). ${ }^{77}$

The CJEU considered online sales to be a "method of marketing", which does not require the physical movement of the customer. Since the contractual clause considerably reduces the ability of an authorised distributor to sell the products to customers outside its contractual territory or area of activity, it is considered as liable to restrict competition in that sector. ${ }^{78}$

Furthermore, the CJEU stated that agreements constituting a selective distribution system are to be considered, in the absence of objective justification, as restrictions "by object". ${ }^{79}$ Considering the manufacturer's need to maintain the prestigious image of its products, the CJEU noted that the products in question were not considered luxury products, but "regular" ones. In that respect, it held that the need to maintain prestigious image is not a per se legitimate aim for restricting competition and thus a contractual clause pursuing such an aim does fall under Article 101(1) TFEU. It concluded that the disposition in question resulting in a ban on the use of the internet for sales, amounts to a restriction by object. ${ }^{80}$

Concerning the question of applying block exemptions, the CJEU took the selective distribution system out of the scope of the block exemption. In fact, the

\footnotetext{
75 I.e. from the Regulation 330/2010

76 I.e. from Article 101(3) TFEU

77 Guidelines on Vertical Restraints, para 52

78 Case C-439/09 Pierre Fabre Dermo-Cosmétique SAS v Président de l'Autorité de la concurrence and Ministre de l'Économie, de l'Industrie et de l'Emploi [2011 EU:C:2011:6499, para 38

79 Ibid., para 39

$80 \quad$ Ibid., para 47
} 
exemption is not to apply to vertical agreements the aim of which is to restrict active or passive sales to end users by members of the system operating at the retail level of trade, without prejudice to the possibility of prohibiting a member of the system from operating out of an unauthorised place of establishment. ${ }^{81}$ The CJEU held that the object of a contract clause contained in its selective distribution contracts, prohibiting de facto the internet as a method of marketing, is a restriction of passive sales (i.e. the possibility to advertise or promote) to end users wishing to purchase online and located outside the physical trading area of the relevant member of the selective distribution system. ${ }^{82}$ It did not accept the argument that a ban on internet sales was analogous to a prohibition on operating out of an unauthorised establishment. According to the CJEU, the term "a place of establishment" refers only to outlets where direct sales take place and not the place from which internet sales services are provided. ${ }^{83}$ Therefore, it ruled that the selective distribution system in question does not fall under the block exemptions.

With regard to individual exception, the Court noted that such a ban may benefit from the exception provided for in Article 101(3) if the conditions set out in that provision are met.

The approach taken by the CJEU in Pierre Faber was severely criticised. Concerning the legal construction that internet is seen as a "method of marketing" and not as a "an unauthorized place of establishment" ${ }^{84}$, some commentators stated that it did not take into consideration the argument that restraints established by vertical agreements can enhance competitiveness within a distributive chain by facilitating better coordination between the participating undertakings, especially leading to a reduction in transaction costs. ${ }^{85}$ Others commented that competition law dispositions were applied too extensively. ${ }^{86}$

The use of the internet is cross-border by its nature and therefore likely to incite parallel trading. In this regard, the problem with free-riding is present. In fact, the

81 The disposition applicable in the case was Article 4(c) of the Commission Regulation (EC) No 2790/1999 of 22 December 1999 on the application of Article 81(3) of the Treaty to categories of vertical agreements and concerted practices [1999] OJ L 336/21 (replaced by Article 4(c) of Regulation No 330/2010)

82 Case C-439/09 Pierre Fabre Dermo-Cosmétique SAS v Président de l'Autorité de la concurrence and Ministre de l'Économie, de l'Industrie et de l'Emploi [2011 EU:C:2011:649, para 54

83 Ibid., para 56

84 Ibid., para 58

85 Romano V. C., ECJ Ruling on the Prohibition of On-line Sales in Selective Distribution Networks, Journal of European Competition Law \& Practice, Vol. 3, Number 4, 2012, p. 346

86 Monti G., Restraints on Selective Distribution Agreements, World Competition, Vol. 36, no. 4, 2013, pp. 489-512 
constant presence of a pharmacist at the sale points involves costs for brick-andmortar distributors, which are not borne by pure online selling platforms ${ }^{87}$

\subsection{Luxury products: the Coty case}

In December 2017, the CJEU delivered the long awaited Coty judgement. Coty is a supplier of luxury cosmetics, which sells its products through a selective distribution system. According to the agreement establishing that system, distributors are allowed to sell the products through the distributor's electronic shop window. However, it prohibits the use of a different business name as well as the visible involvement of a third party undertaking which is not an authorised distributor. The distributor Parfümerie Akzente engaged in the distribution of products through a third-party platform "amazon.de". Coty took legal action and at the appeal instance the Oberlandesgericht Frankfurt am Main (Frankfurt am Main Higher Regional Court) requested a preliminary ruling.

The first two preliminary questions deal with the relationship between selective distribution and Article 101(1) TFEU in general terms: 1) does the selective distribution system for luxury goods designed, primarily, to preserve the luxury image of those goods comply with that provision and 2) does that provision preclude the contractual clause prohibiting the use of third-party platforms for the online sale of the contract goods. The other two questions concern the application of the exemption provided in Regulation 330/2010.

The difference between Pierre Fabre and Coty is that the former case concerned an absolute ban on internet sales, which was not the issue in the latter. In Pierre Fabre the CJEU had stated that, as regards cosmetics, "the aim of maintaining a prestigious image is not a legitimate aim for restricting competition". ${ }^{88}$ In Coty, it narrowed the possible interpretations stating that its observations made there must be read and interpreted in the specific context of that case. ${ }^{89}$

The CJEU started its argumentation by repeating that the selective distribution network of luxury products is not prohibited by Article 101(1) TFEU, if the resellers are chosen on the basis of objective criteria of a qualitative nature, laid down uniformly for all potential resellers and not applied in a discriminatory fashion, if the characteristics of the product in question necessitate such a network

\footnotetext{
87 Romano, op. cit., note 85, p. 347

88 Case C-439/09 Pierre Fabre Dermo-Cosmétique SAS v Président de l'Autorité de la concurrence and Ministre de l'Économie, de l'Industrie et de l'Emploi [2011 EU:C:2011:649, para 46

89 Case C-230/16 Coty Germany GmbH v Parfümerie Akzente GmbH [2017] EU:C:2017:941, paras 31 and 34
} 
in order to preserve its quality and ensure its proper use and, finally, if the criteria laid down do not go beyond what is necessary to attain that goal. ${ }^{90}$

When it comes to the nature of products, the CJEU relied on the objective justification theory ${ }^{91}$ and ruled that their luxury nature per se is an objective justification for the establishment of a selective distribution system and for removing it from the application of Article 101(1) TFEU. ${ }^{92}$ In order to support its analysis, the CJEU referred to Copad. As the aura of luxury distinguishes luxury products from non-luxury ones, an impairment to that aura is likely to affect the actual quality of those goods. ${ }^{93}$

Against that background, the CJEU assessed the ban on use of the third-party platform. It analysed whether the prohibition is proportionate to the objective pursued. In this relation it examined two questions, i.e. whether such a prohibition is appropriate for preserving the luxury image of those goods and whether it goes beyond what is necessary to achieve that objective. ${ }^{94}$

With respect to the first issue, the CJEU held that the absence of a contractual relationship between the supplier and the third-party platform presents an obstacle to ensuring compliance with the quality standards. ${ }^{95}$ It stated that the obligation imposed on authorised distributors to sell the contract goods online solely through their own websites provides the supplier with a guarantee that those goods will be exclusively associated with the authorised distributors. Furthermore, it enables the supplier to ensure that the products are sold online in an environment that corresponds to the objective qualitative conditions. Finally, it is the association of luxury products with authorised distributors' websites that contributes to that luxury image among consumers. ${ }^{96}$

Regarding the second issue, the CJEU referred to the Commission's E-commerce Sector Inquiry ${ }^{97}$ and to its finding that, even though the third-party platforms are

\footnotetext{
$90 \quad$ Ibid., para 24

${ }^{91}$ Wijckmans F., Coty Germany GmbH v Parfümerie Akzente GmbH: Possibility in Selective Distribution System to Ban Sales via Third-Party Platforms, Journal of European Competition Law \& Practice, Vol. 9, No. 6, 2018, pp. 372

92 Case C-230/16 Coty Germany GmbH v Parfümerie Akzente GmbH [2017] EU:C:2017:941, paras 2529

93 Ibid., para 25

94 Ibid., para 43

95 Ibid., para 56

$96 \quad$ Ibid., paras 44 to 53

97 Report from the Commission to the Council and the European Parliament, Final report on the E-commerce Sector Inquiry, COM(2017) 229 final, 10/5/2017, [http://ec.europa.eu/competition/antitrust/ sector_inquiry_final_report_en.pdf] Accessed 15.04.2019
} 
growing in importance, online webshops of the authorised distributors remain the main online distribution channel, to conclude that the prohibition does not go beyond what is necessary to achieve the object of preserving the luxury image of those goods. ${ }^{98}$

Lastly, the CJEU addressed the question whether the prohibition to sell through third-party platforms constitutes a restriction of their customers or a restriction of passive sales to end users, within the meaning of Article 4 (b) and (c) of Regulation 330/2010. In order to answer the question, it analysed whether the contractual clause restricts the customers to whom authorised distributors can sell the luxury goods or whether it restricts authorised distributors' passive sales to end users. ${ }^{99}$

The CJEU clearly departed from Pierre Fabre, clarifying that the prohibition in question does not refer to the use of the internet as a means of marketing of the products. It then stated that it is not possible to define or identify a group of third-party platform customers within the group of online purchasers. It added that distributors can use online search engines, and that customers are usually able to find the online offer of authorised distributors by using such engines. The final conclusion was that the prohibition does not amount to a restriction of customers of distributors or a restriction of their passive sales to end users. ${ }^{100}$

Coty is seen as an important case in the development of EU competition law. ${ }^{101}$ It was welcomed by the commentators who stated that it ended the debate regarding the treatment of the third-party platform ban between the Commission and Member States' competition authorities, which considered that the ban presents an appreciable restriction of competition. ${ }^{102}$ Others highlighted the factual circumstances of each case, concluding that the approaches of national authorities were not in contrast with the new developments of EU law. ${ }^{103}$

The following chapters deal with decisions delivered by national authorities.

98 Case C-230/16 Coty Germany GmbH v Parfümerie Akzente GmbH [2017] EU:C:2017:941, paras 54 and 55

99 Ibid., paras 62 to 64

100 Ibid., paras 65 to 69

101 Winter, op.cit., note 6

102 Wijckmans, op. cit., note 91, p. 374. Waelbroeck D.; Davie Z.; Coty, Clarifying Competition Law in the Wake of Pierre Fabre, Journal of European Competition Law \& Practice, Vol. 9, No. 7, 2018, pp 431-442

103 Reisinger, op. cit., note 10., p. 4; Zelger B., Restrictions of online sales and vertical agreements: Bundeskartellamt vs. Commission? Why Coty and Asics are compatible, European Competition Journal, Vol. 14, No. 2-3, 2018, pp. 445-461 


\section{SELECTIVE DISTRIBUTION SYSTEMS AND THIRD-PARTY PLATFORMS SCRUTINISED BY NATIONAL AUTHORITIES}

\subsection{Ban on using brand names as a keyword and price comparison websites: the Asics case}

Just a week after the CJEU delivered its judgement in Coty, the German Bundesgerichtshof (Federal Supreme Court) ${ }^{104}$ confirmed the decisions of the Oberlandesgerichts Düsseldorf (Duesseldorf Higher Regional Court) ${ }^{105}$ and the Bundeskartellamt (Competition authority) ${ }^{106}$, finding that restricting the access to price comparison websites constitutes an infringement of competition law. ${ }^{107}$

In 2013, the Bundeskartellamt started investigating Asics' German online distribution system of sporting goods (running shoes). In the course of the proceedings, the focus was limited to the prohibition on the use of Asics brand names on third party websites as a key word and to the prohibition on supporting price comparison engines. The authority held that the selective distribution system contained restrictions "by object" under Article 4(c) of Regulation 330/2010. The selective distribution system also contained a ban on the advertising or sale of Asics products via third-party websites. However, this issue was not analysed, since the Bundeskartellamt found that the determination of the first two mentioned restrictions were sufficient.

The German competition authority held that the distribution system used by Asics was not a purely qualitative distribution system, but a combination of a qualitative and quantitative selective distribution system. For this reason, an exemption from the prohibition of Article 101 (1) TFEU was not possible.

Firstly, the prohibition on the use of brand names as a keyword in paid search engine advertising enables authorised distributors to improve the searchability of their online offer for end customers, enabling them to gain new customers

104 Bundesgerichtshof Beschluss KVZ 41/17 vom 12. Dezember 2017 in der Kartellverwaltungssache, DE:BGH:2017:121217BKVZ41.17.0, [http://juris.bundesgerichtshof.de/cgi-bin/rechtsprechung/ document.py?Gericht=bgh\&Art=en\&Datum=Aktuell\&Sort=12288\&nr=80673\&pos=25\&anz=515] Accessed 15.03.2019

105 Oberlandesgerichts Düsseldorf, Beschluss KVZ 41/17 vom 5. April 2017

106 Bundeskartellamt Beschluss B2-98/11 vom 26. August 2015 in dem Verwaltungsverfahren, [https:// www.bundeskartellamt.de/SharedDocs/Entscheidung/DE/Entscheidungen/Kartellverbot/2015/B298-11.pdf?_blob=publicationFile\&v=3] Accessed 15.03.2019. For a summary in English see Bundeskartellamt, Case Summary: Unlawful restrictions of online sales of ASICS running shoes, [https:// www.bundeskartellamt.de/SharedDocs/Entscheidung/EN/Fallberichte/Kartellverbot/2016/B2-9811.pdf?_blob=publicationFile\&v=2] Accessed 15.03.2019

107 For a general overview of decisions of German courts see Hoffmann F., Restrictions on Selective Distribution Systems on the Internet, CPI Antitrust Chronicle, October (2), 2014, pp. 1-9 
through the internet. A restriction of this kind may be a legitimate limitation of the sales possibilities of selective distributors if the following conditions are fulfilled: the distribution system provides a restriction on offline distributors in a comparable form (principle of equivalence) ${ }^{108}$, it constitutes a legitimate quality requirement for the sales or it is justified from the point of view of trademark law considerations ${ }^{109}$. The prohibition on the use of brand names does not fulfil any of these conditions and thus presents a restriction by object.

Secondly, the prohibition on authorised distributors from making active use of price comparison engines to promote sales prevented end customers who particularly value certain criteria (such as the price) to make use of special search engines to help them "filter out" suitable offers. The Bundeskartellamt held that there were no qualitative considerations that could justify the prohibition of support for price comparison engines. In particular, the per se prohibition was not justified as a measure of protecting the brand image or of tackling a free-rider problem.

On appeal, the Oberlandesgerichts Düsseldorf upheld the Bundeskartellamt's decision. ${ }^{110}$ The competition authority had based in essence its decision only on the complete ban of price comparison websites, finding the ban to be incompatible with competition law. Therefore, the Oberlandesgerichts Düsseldorf limited itself to that finding, and addressed only the matter of price comparison engines. It held that such a prohibition deprives distributors of an opportunity to advertise and sell online effectively, and concluded that the prohibition was not justified by branding considerations or the need for staff to provide customer counselling services. In fact, consumers would not necessarily need advice before purchasing running shoes, and may prefer to look up such information on the internet. ${ }^{111}$

Confirming the first-instance decision, the Bundesgerichtshof stated that a ban on price comparison websites prevented consumers from finding distributors' offers, and was capable of substantially restricting distributors' online sales. Considering the large amount of products offered online, and the considerable number of dis-

\footnotetext{
108 Guidelines on Vertical Restraints, para 56

109 In that regard, see joined cases C-236/08 and C-238/08 Google France and GoogleECLI:EU:C:2010:159

110 Cole M., Asics' online sales restrictions confirmed as illegal by Duesseldorf Higher Regional Court, 8 April 2017, [https://www.covbrands.com/2017/04/08/asics-online-sales-restrictions-confirmed-as-illegal-by-duesseldorf-higher-regional-court/?_ga=2.242657154.1828475972.15534909552080505729.155349095] Accessed 15.03.2019

111 In addition, the Duesseldorf Higher Regional Court refused to permit further appeal to the Federal Supreme Court as no fundamental questions of law were raised. It found that there were no reasons to refer the matter to the CJEU for preliminary ruling. The Supreme Court agreed, See Bundesgerichtshof Beschluss KVZ 41/17 vom 12. Dezember 2017 in der Kartellverwaltungssache, DE:BGH:2017:121217BKVZ41.17.0, para 9
} 
tributors, it found price comparison websites important for both consumers and distributors, since they enable consumers to identify which distributors offer the product they selected, and on which conditions. It concluded that a distributor can substantially enhance its chances of sales by connecting with price comparison websites. ${ }^{112}$

The Bundesgerichtshof held that Pierre Fabre and Coty were not applicable. Firstly, the restriction on the use of price comparison engines did not amount to a total ban on internet sales (which was the case in Pierre Fabre), but only limited the use of one online sales channel. Secondly, the distribution system set up by Asics did not concern luxury products (which was the case in Coty). ${ }^{113}$ It sided with the Bundeskartellamt's conclusion that the established general prohibition of advertising through price comparison websites constituted a restriction "by object". ${ }^{114}$

Some commentators agreed that the stance adopted in Asics is not in line with the CJEU's position. ${ }^{15}$ Others considered the reasoning of the German authorities to be founded in the concrete circumstances of the case at hand. ${ }^{116}$

\subsection{Ban of internet sales: the Stibl case}

The first decision based on the Coty judgement was issued in France by the Autorité de la concurrence (competition authority) in the Stibl case. ${ }^{117}$

Stihl, a manufacturer of mechanical garden tools (chainsaws, hedge trimmers and lawnmowers), operated through a selective distribution network which required its distributors to hand-deliver the products to their customers and prohibited sales on online marketplaces. Even though the distribution contract did not explicitly prohibit online sales, the conclusion of the competition authority was that the requirement to hand-deliver the products amounted to a de facto ban on online sales, since it forced the online purchaser to go in person to the shop to collect the product, and was thus anticompetitive. ${ }^{118}$

\footnotetext{
112 Ibid., paras 23-25

113 Ibid., para 22

114 Ibid., para 9

115 Waelbroeck; Davies, op. cit., note 102, p. 431

116 Reisinger, op. cit., note 10, p. 4

117 Autorité de la concurrence, Décision n 18-D-23 du 24 octobre 2018 relative à des pratiques mises en œuvre dans le secteur de la distribution de matériel de motoculture

118 Autorité de la concurrence, Décision n 18-D-23 du 24 octobre 2018 relative à des pratiques mises en œuvre dans le secteur de la distribution de matériel de motoculture, para 37
} 
The Autorite de la concurrence held that the technicality of the products justified the selective distribution system. Concerning internet sales, two different issues emerged: the legitimacy of the ban of online sales and the ban of using third-party platforms.

In regard to the total ban of online sales, the authority did not accept the argumentation put forward by Stihl, i.e. that the hand-delivery requirement only affected the conditions of delivery and not the ability to purchase the product online and that the requirement was necessary to ensure the safe use of its products. ${ }^{19}$

Firstly, it found that the consequences of the distinction between purchase and delivery, which the authority defines "artificial", consist in depriving online sales of their main benefit, i.e. not having to go to the store in person. ${ }^{120}$ Secondly, the requirement to hand-deliver the products was disproportionate with regard to its objective of ensuring the safety of its products. Its conclusion was based on the fact that the applicable safety regulation did not impose such condition nor was it practiced by Stihl's competitors. ${ }^{121}$

The authority found that an economic operator can in general go beyond what is provided by the applicable safety regulation and that it is legitimate for it to differentiate itself from its competitors by providing additional service. However, these additional safety requirements for "dangerous" products are not enough for justifying the complete ban of online sales, since authorised distributors should be allowed to sell the products on their own websites. ${ }^{122}$

The ban of using third-party platforms is a different issue. The authority addressed the question whether Coty, originally intended for luxury products, could be extended to other types of products. Its answer is positive.

The authority used the argumentation on "dangerous" products to justify the third-party platforms ban. It stated that such a third-party platform ban could be legitimate, since it ensures consumer safety and brand image, on the one hand, and allows Stihl to control that its distributors abide by a number of information obligations, on the other. As in Coty, the authority based its reasoning on the existence of a contractual relationship between the supplier and the distributor. Since there was no such contractual relationship between Stihl and third-party platforms, Stihl was not able to exert proper control over the sale of its goods. ${ }^{123}$

\footnotetext{
$119 \quad$ Ibid., para 36

120 Ibid., paras 164-166

$121 \quad$ Ibid., para 192

122 Ibid., para 181

123 Ibid., paras 283-285
} 
The decision delivered by the Autorité de la concurrence is not final. In fact, Stihl contested the decision before the Cour d'appel de Paris (Paris Court of Appeal) asking for its annulment. In addition, Stihl asked for a stay of the execution order issued by the authority. ${ }^{124}$ The president of the Court of Appeal granted the request and pronounced a stay of the execution order. ${ }^{125}$

For the time being, the decision of the French competition authority does not affect Stihl's distribution system. It is to be seen whether it will resist the critics pointed out before the appeal court and become the reference point for future decisions.

\section{IMPLICATIONS}

Decisions delivered after Coty by national authorities show that the CJEU's judgement can be interpreted in different ways. On the one hand, Coty could be seen as having no relevance for trademarked goods that are not considered luxury goods (as it results from Asics). On the other, its application can be extended to nonluxury products (as it results from Stihl).

Also, it follows that complete bans of internet sales are considered to constitute a breach of competition law. Only use of third-party platforms can be restricted. The key aspect justifying the compatibility of third-party platform restriction with competition law is the possibility of finding the distributor on the internet (e.g. through a third party price comparison website).

These issues will be considered in the following chapters.

\subsection{The nature of the products: luxury and non-luxury}

The image of a luxury product is its essential component. Suppliers choose to invest in the image because that is what consumers demand. From an economic point of view, the adoption of a selective distribution system instead of a "mass

124 Autorité de la concurrence fined Stihl with 7,000,000 euros. In addition, it issued four injunctions, the most important being to amend, within 3 months from the notification of the decision, its selective distribution contracts in order to stipulate in clear terms that the authorized distributors had from then on the possibility to sell all STIHL \& Viking's products online, without requiring a "hand-over" to the buyer. Autorité de la concurrence, Décision n $18-\mathrm{D}-23$ du 24 octobre 2018 relative à des pratiques mises en œuvre dans le secteur de la distribution de matériel de motoculture, paras 319-320

125 Saez E., Aftermath of the STIHL case: The first President of the Paris Court of Appeal ordered a stay of execution regarding the four injunctions pronounced by the French Competition authority, 30 January 2019, [https://www.nomosparis.com/en/aftermath-of-the-stihl-case-the-first-president-ofthe-paris-court-of-appeal-ordered-a-stay-of-execution-regarding-the-four-injunctions-pronounced-by-the-french-competition-authority-2/] Accessed 15.03.2019 
market" distribution model generates significant costs. Greater expenditure is undertaken at the retail level regarding aspects such as sales assistance, an exclusive showroom, comfort for the shopper and a strong retail brand name. The same goes for high-quality and high-technology products.

In practice, the retailer has a higher margin, and the supplier needs to tolerate it, since it allows the retailer to recover its investment costs. The benefit for the supplier is that the retailers' contribution to the product image adds a component to the final product, as perceived by both the consumer and those who interact with him. ${ }^{126}$

When deciding about the legitimacy of the selective distribution system, two elements reflect the nature of the product: whether the restriction is appropriate to achieve the objective pursued, i.e. to preserve its quality, luxury image or proper use, and whether it goes beyond what is necessary to achieve that objective.

In Coty, the CJEU relied on its trademark jurisprudence and found that the assessment of quality of luxury products goes beyond their material characteristics. In fact, the quality of these products can be equated to their "allure and prestigious image which bestows upon them an aura of luxury". ${ }^{127}$ The selective distribution system is an effective means to preserve that quality component and therefore a luxury image is a legitimate aim for restricting competition.

The question that was left open after Coty is whether that judgement is limited to luxury goods.

At first sight, the answer would be negative. It results from the CJEU's decision in Pierre Fabre that the aim of maintaining a prestigious image of a non-luxury product is not a legitimate aim for restricting competition. ${ }^{128}$ Comparing the two decisions, it seems that the CJEU differentiates "luxury cosmetics" in Coty from regular "cosmetic and personal care products" in Pierre Fabre.

126 For a comprehensive discussion on the issue see Buettner T.; Coscelli A.; Vergé T.; Winter R. A., An Economic Analysis of the Use of Selective Distribution by Luxury Goods Suppliers, European Competition Journal, Vol. 5, Issue 1, 2009, pp. 201-226; Kinsella Obe S.; Melin H.; Schropp S., Comments on the CRA Paper Entitled "An Economic Analysis of the Use of Selective Distribution by Luxury Goods Suppliers", European Competition Journal, Vol. 5, Issue 1, pp. 227-260; Buettner T.; Coscelli A.; Vergé T.; Winter R. A., Selective Distribution by Luxury Goods Suppliers: A Response to Kinsella Et Al, European Competition Journal, Vol. 5, Issue 2, 2009, pp. 613-621

127 Case C-230/16 Coty Germany GmbH v Parfümerie Akzente GmbH [2017] EU:C:2017:941, para 25

128 Case C-439/09 Pierre Fabre Dermo-Cosmétique SAS v Président de l'Autorité de la concurrence and Ministre de l'Économie, de l'Industrie et de l'Emploi [2011 EU:C:2011:649, para 46 
As it was mentioned earlier, the basic principles concerning the legitimacy of selective distribution of luxury goods were developed by the Court of First Instance in the 1990s. However, the CJEU did not rely on the Leclerc cases to support its analysis. ${ }^{129}$ Instead, it relied on Copad, a case concerning the exhaustion of trademark rights. Even though the factual context is very similar, it is unclear why the CJEU took into consideration the findings emerging from trademark law and included them into its assessment regarding a selective distribution system in competition law. In fact, the legal issues addressed in the two cases are rather different. Copad concerned a breach of licensing agreement, while Coty concerned the legality of sale agreements. In Copad, the trademark owner claimed that it could directly reach through to a third party outside the selective distribution system under trademark law. It could be stated that both licensing and sales agreements are vertical agreements which restrict the distributors of branded goods. ${ }^{130}$ However, it remains a fact that the CJEU did not provide for reasons that explain how issues concerning trademark law and competition law can be reconciled. ${ }^{131}$

It results from Copad that there is a direct link between the image of the product and the distribution method. In relation to luxury products, the distribution method becomes a factor of quality. In fact, the "aura of luxury" is created by elaborate and expensive retail services. ${ }^{132}$ In Coty, the CJEU focused on the fact that there is no contractual relationship between the manufacturer and the third-party platform. Due to the lack of that relationship, the manufacturer cannot perform adequate controls nor take action in cases of any deterioration of its luxury image that may occur if the products are represented inappropriately.

A different look at the two cases could bring to a different result. If the logic expressed in Copad is applied in Coty, in case of deterioration of the luxury image of its products, Coty could enforce its trademark rights directly against non-authorised third-party online resellers used by authorised distributors. In that case, the restriction on the use of third-party platforms could be put into question.

On the other side, Copad is a case decided in an offline environment. It could also be argued that it cannot be wholly applicable in the online environment. ${ }^{133}$

\footnotetext{
129 They were mentioned only briefly by the advocate general. Case C-230/16 Coty Germany GmbH v Parfümerie Akzente GmbH, Opinion of advocate General Wahl [2017] EU:C:2017:603, paras 65 and 70

130 Schmidt-Kessen M. J., Selective Distribution Systems in EU Competition and EU Trademark Law, Journal of European Competition Law \& Practice, Vol. 9, No. 5, 2018, p. 313

131 Waelbroeck; Davies, op. cit., note 102, p. 433

132 Schmidt-Kessen, op. cit., note 126, pp. 312-313

133 Ibid, p. 314
} 
The CJEU did not provide further guidance on the issue of when a product might be considered to be a luxury product. The mere fact that a product is of high quality and is sold under a registered trademark does not automatically give this product an "aura of luxury". The "aura of luxury" depends on the question of how the products are sold. And it is exactly this "how" that is absent from the CJEU's case law.

When considering the applicability of Coty to the distribution of non-luxury products, the Stihl case provides an adequate factual background. The object of the selective distribution system is to ensure the quality requirement through before- and after-sale services. Is this objective comparable to the objective of preserving the luxury image?

The Autorité de la concurrence held that it is. And its analysis is rather convincing. In fact, there is a number of services that contribute to the quality of the products, such as information and advice concerning the proper use, video demonstrations available on distributors' websites and telephone "hotline" services provided by competent personnel. In addition, a survey carried out in the sector of the distribution of garden equipment showed that more than $90 \%$ of distributors used only its own online shops for online selling. The authority found these elements essential for the quality of goods and brand identity. ${ }^{134}$

Concerning the applicability of Coty to trademarked non-luxury goods, it should be noted that in both Pierre Fabre and Coty the compatibility of a selective distribution system for luxury goods with Article 101(1) was not directly relevant. In fact, the market share in both cases did not exceed the threshold set out in Article 3 of Regulation 330/2010. The question that emerges is why the referring court in Coty even addressed this issue, if it was irrelevant for the dispute. ${ }^{135}$

In this regard, according to the Guidelines on Vertical Restraints, the application of the Regulation 330/2010 does not depend on the nature of the products sold through the selective distribution system. ${ }^{136}$ Accordingly, the ban on third-party platforms (if restrictive of competition) should benefit from the block exemption irrespective of the nature of the products involved. The only conditions are that

\footnotetext{
134 Autorité de la concurrence, Décision n ${ }^{\circ} 18-\mathrm{D}-23$ du 24 octobre 2018 relative à des pratiques mises en œuvre dans le secteur de la distribution de matériel de motoculture, paras 282-288

135 Waelbroeck; Davies, op. cit., note 102, p. 433

136 Guidelines on Vertical Restraints, para 176. It could be argued that distinction between "passive" and "active" sales has no practical relevance in the context of selective distribution. Hoffmann, op. cit., note 107 , p. 3
} 
it is necessary for the product in question and that the criteria are implemented objectively and in a non-discriminatory manner. ${ }^{137}$

\subsection{The extent of the prohibition}

When addressing the legality of a selective distribution systems, the starting point adopted by the CJEU is that selective distribution agreements necessarily affect competition in the Internal market. ${ }^{138}$ In Coty, the luxury nature of the goods is accepted as such an objective justification to remove the selective distribution system out of the scope of Article 101(1) TFEU. ${ }^{139}$ Coty could be interpreted as there is no Article 4 (b) and (c) of Regulation 330/2010 issue due to the nature of the products. However, this interpretation is not correct. ${ }^{140}$

According to Article 4 (b) and (c) of Regulation 330/2010, the third-party platform ban may be considered a restriction "by object" if it restricts active or passive sales to end users or if it restricts the territory into which, or customers to whom, a distributor may sell contract goods.

In the Commission's Guidelines on Vertical Restraints, the internet as a distribution channel is considered as a form of "passive sale". ${ }^{141}$ Passive sale takes place when the distributor responds to unsolicited requests from individual customers. The question that emerges is why it deserves a special treatment.

The free-riding argument presupposes that pure online retailers take advantages of the investment made by traditional bricks-and-mortar distributors on product's image, advertising and consumer drawing power to increase demand for the products. If not prevented, the consequence of that is the underinvestment in activities that consumers value and are willing to pay for. Therefore, suppliers must be able to exclude any retailers that generate negative externalities. ${ }^{142}$

137 Eberhardt A., Why the discriminatory application of criteria in selective distribution systems is block exempted under Regulation 330/2010, European Competition Journal, Vol. 11, Issue 1, 2015, pp. 168192

138 Case C-230/16 Coty Germany GmbH v Parfümerie Akzente GmbH [2017] EU:C:2017:941, para 23

139 Ibid., para 25-29

140 Wijckmans, op. cit., note 91, p. 374

141 Guidelines on Vertical Restraints, para 56. The concepts of active and passives sales were developed at a time where internet was not a regular method of communication. A restriction of passive sales referred to a prohibition imposed on a distributor to sell into another distributor's exclusive territory, while active sales concerned the activity of approaching customers allocated to another distributor

142 Carlton D. W.; Chevalier J. A., Free-riding and Sales Strategies for the Internet, The Journal of Industrial Economics, Vol. XLIX, No. 4, 2001, pp. 441-461 
Online shopping impacts distribution strategies. ${ }^{143}$ In order to cope with internet as a new distribution format and to control free-riding, suppliers tend to develop new restrictions on internet retailers. The resolution of the free-ride issue is only possible by setting up quality standards and by choosing distributors which commit to satisfy these standards, i.e. offer the appropriate retail environment and related services to the consumer.

In the context of online sales, the quality standards may refer to the quality of distributors' websites so that products are displayed in a way that avoids any confusion with concurrents' products. In this regard, the supplier may require prior approval of information published on the webpage, the use of logos, colours, banners and formatting, etc. On the other hand, some requirements may be considered disproportionate, e.g. stipulating excessive specifications for the presentation of the product. ${ }^{144}$

The CJEU follows that logic and is ready to exclude internet retailers from the network of "pure-play". In Pierre Fabre, the CJEU stated that a contractual clause prohibiting de facto the internet as a method of marketing, at the very least has as its object the restriction of passive sales to end users wishing to purchase online and located outside the physical trading area of the relevant member of the selective distribution system. ${ }^{145}$ This conclusion was softened in Coty, where the CJEU assessed the clause at issue by applying the principle of proportionality. ${ }^{146}$

Decisions issued by the German Bundesgerichtshof and the French Autorite de la concurrence are compatible with the CJEU's reasoning. This leads to the conclusion that agreements between producers and retailers, which completely prohibit the retailer from using the internet to sell branded goods (i.e. absolute ban on internet sales), breach competition law, since they are deemed disproportionate. On the other hand, milder online restrictions could be in conformity with competition law. In other words, the distributor has to be allowed to set up its own web page and sell branded products through it. The supplier may require quality standards, but it cannot prevent online selling.

143 An economic model of the consumer demand for a luxury good shows that the incentives for manufacturers and consumers not to use the online distribution channel may be aligned. The intervention in the manufacturers' decisions could potentially have an ambiguous effect on consumer utility. Pruzhansky V., Luxury goods, vertical restraints and internet sales, European Journal of Law and Economics, Vol. 38, Issue 2, 2014, pp. 227-246

144 Colangelo G.; Torti V., Selective distribution and online marketplace restrictions under EU competition rules after Coty Prestige, European Competition Journal, Vol. 14, No 1, 2018, pp. 89-90

145 Case C-439/09 Pierre Fabre Dermo-Cosmétique SAS v Président de l'Autorité de la concurrence and Ministre de l'Économie, de l'Industrie et de l'Emploi [2011 EU:C:2011:649, para 54

146 Case C-230/16 Coty Germany GmbH v Parfümerie Akzente GmbH [2017] EU:C:2017:941, para 65 
The above statement has to be nuanced. In fact, absolute marketplace bans are not hardcore restrictions and thus a case-by-case analysis of the effects is required for both luxury and non-luxury products. ${ }^{147}$ The key element is whether there are less restrictive means of protecting the brand image and whether the distributor has other options of selling the products online. ${ }^{148}$

Some commentators remarked that the fact that some luxury goods producers have decided not to use pure-online retailers to distribute their products has not hindered the development of internet distribution. The proof is that almost all exclusive brands can currently be purchased on the internet via the brand owners' own websites or the authorised distributors' sites. ${ }^{149}$ However, a problem arises in this context, and it relates to small and medium enterprises which do not have the means to establish and maintain a selling platform of their own. For them, the milder restriction presents a hard burden in terms of market access. ${ }^{150}$

When it comes to third-party platforms, it results from the analysed decisions that the key issue is whether distributors are prevented from advertising the products. Therefore, if the distribution system does not prevent distributors from referencing their websites on third-party platforms (e.g. search engines, comparison websites), it is considered compatible with Article 4 (b) and (c) of the Regulation $330 / 2010$, since it enables customers to access the distributors products through search engines.

Finally, there are authors who openly criticize traditional stances on the free-riding argument in relation to branded goods. In fact, there might be a new form of reverse free-riding, or free-riding off the internet. Pure online retailers also invest in their distribution channel, creating rich product information to allow consumers to make informed purchasing decisions. It could be argued that consumers may take advantage of that distribution format to research and choose a product before purchasing it in a bricks-and-mortar store. ${ }^{151}$

Online distribution channels like Amazon or eBay continue to drive huge sales. Nevertheless, it seems that luxury brands do not envisage using this type of distribution in their future. Until now, they managed to circumvent it. However,

\footnotetext{
147 Colangelo, op. cit., note 144, pp. 105-106

148 Witt A. C., Restrictions on the use of third-party platforms in selective distribution agreements for luxury goods, European Competition Journal, Vol. 12, Nos. 2-3, 2016, pp. 435-461

149 Buettner et. al., op. cit., note 126, p. 226

150 Waelbroeck; Davies, op. cit., note 102, p. 440

151 Accardo G., Vertical Antitrust Enforcement: Transatlantic Perspectives on Restrictions of Online Distribution Under EU and US Competition Laws, European Competition Journal, Vol. 9, No. 2, 2013, p. 243
} 
many do not see this approach sustainable in the long run. ${ }^{152}$ Luxury brands will eventually have to find a way of taking advantage of third-party platforms while protecting the image of their trademark and without jeopardizing their business.

\section{CONCLUDING REMARKS}

Coty is an important decision, addressing the contemporary challenges to distribution in EU law. Even though Pierre Fabre could be seen as a departure from CJEU's earlier jurisprudence concerning high quality products, Coty reaffirms the importance of the nature of luxury goods in the context of selective distribution restraints.

To reaffirm the position of luxury goods, the CJEU based its decision on its trademark jurisprudence. Still, Coty leaves some questions open, e.g. what is the relationship between trademark and competition law, what are the criteria for distinguishing different trademarked products, and whether that logic is applicable to non-luxurious goods.

Two national decisions show that Coty could be interpreted differently. The respective restrictions in the mentioned national decisions are discussed in the light of the specific underlying facts and circumstances of each case. It follows that the nature of the product for which the selective distribution systems were established is different. Luxury products have appeared to meet the criteria of compatibility with competition rules much more easily than the "regular" ones.

A closer analysis shows that the debate concerning the nature of the product (luxury versus non-luxury) is not that relevant in the context of vertical agreements satisfying the exemption criteria provided for in the Regulation 330/2010. What is important is whether the restriction amounts to a territory or sales restriction to end users. It results from the analysed decision that a complete ban of online sales presents a breach of competition law, while more nuanced restrictions are seen as compatible.

The emergence of online platforms is changing distribution models. The analysed decisions show that trademark owners are reluctant to accept that their products are sold through third-party channels, over which they have no control. So far, trademark owners managed to keep the big third-party platforms out of their

152 Danziger P. N., Amazon Vs. Coty: Coty May Have Won The Battle, But Amazon Will Still Win The War, Forbes, 12 December 2017, [https://www.forbes.com/sites/pamdanziger/2017/12/12/amazonvs-coty-coty-may-have-won-the-battle-but-amazon-will-still-win-the-war/\#1cefdd9570e2] Accessed 15.03.2019 
business. This is especially true for trademark owners that have luxury brands in their portfolio.

Trademark owners need to keep their own line of distribution open. It is still unsure whether they will finally embrace the possibilities offered by big online platforms (such as eBay or Amazon) and in which manner. Since online distribution formats are constantly evolving, one can argue that in the long run the biggest online platforms will outreach authorised distributors' webshops and eventually conquer the luxury brands market.

However, in the short and medium run, it is the impression of the authors that the CJEU will be more inclined towards the protection of trademarks rights. When it comes to luxury products, the attribute "luxury" does not depend on the material characteristics of the product in question, but on the marketing strategy of the trademark owner. The marketing concept is purely a matter of choice for the undertaking concerned. ${ }^{153}$ The selective distribution systems seem to best accommodate the distribution of luxury products. ${ }^{154}$ There is a strong link between the "aura of luxury" perceived by the consumers and the amount of funds invested in the marketing strategy. Therefore, it could be concluded that the more the trademark owner invests in its marketing strategy, the easiest is for him to prove the "quality" component of its product and the need to protect it.

The same could be said for technical and high-end products. The reputation of their trademark also depends on the marketing strategy developed by the trademark holder and thus on the funds invested in it. This investment should be protected in the same way.

In the recent case law the CJEU expanded the concepts of "specific subject matter" and "essential function" of trademark providing protection to its advertising and investment functions. In Google France, a case dealing with the use of a thirdparty trademark as a keyword for triggering the display of Google ads, the CJEU stated that the trademark owner is entitled to a protection when that use of the trademark by a third party adversely affects the owner's use of its mark as a factor in sales promotion or as an instrument of commercial strategy. ${ }^{155}$ In Interflora, a

153 This position is widely accepted in practice. See e.g. European Union Intellectual Property Office, Fourth Board of Appeal, R 1656/2018-4 Paul Reed Smith Guitars, Limited Partnership, decision of 1 April 2019, para 25

154 Kunda; Butorac Malnar, op. cit., note 11, p. 1771

155 Joined cases C-236/08 to C-238/08 Google France SARL and Google Inc. v Louis Vuitton Malletier SA (C-236/08), Google France SARL v Viaticum SA and Luteciel SARL (C-237/08) and Google France SARL $v$ Centre national de recherche en relations humaines (CNRRH) SARL and Others (C-238/08) [2010] EU:C:2010:159 
similar case, the CJEU stated that a trademark may also be used by its proprietor to acquire or preserve a reputation capable of attracting consumers and retaining their loyalty. Therefore, an unauthorized use by a third party would present a trademark violation if such use substantially interfered with the proprietor's use of its trade mark to acquire or preserve a reputation capable of attracting consumers and retaining their loyalty. ${ }^{156}$

The descriptions of the advertising and investment functions of a trademark provided by the CJEU are very broad and could be used in the context of selective distribution and the online environment. Especially since it is not required that the unauthorised use by a third party affects the function of indicating origin.

\section{REFERENCES}

\section{BOOKS AND ARTICLES}

1. Accardo G., Vertical Antitrust Enforcement: Transatlantic Perspectives on Restrictions of Online Distribution Under EU and US Competition Laws, European Competition Journal, Vol. 9, Issue 2, 2013, pp. 225-340

2. Art J.-Y.; Van Liedekerke D., Developments in EC Competition Law in 1996 - an Overview, Common Market Law Review, Vol. 34, Issue 4, pp. 895-956

3. Bailey D.; John L. E. (eds.), Bellamy \& Child: European Union Law of Competition (8th Edition), Oxford University Press, Oxford, 2018

4. Bretagne-Jaeger D., La distribution sélective des parfums de luxe consacrée à Luxembourg, Gazette du palais Paris, No. 159-161, 1997, pp. 11-14

5. Buettner T.; Coscelli A.; Vergé T.; Winter R. A., An Economic Analysis of the Use of Selective Distribution by Luxury Goods Suppliers, European Competition Journal, Vol. 5, Issue 1, 2009, pp. 201-226

6. Buettner T.; Coscelli A.; Vergé T.; Winter R. A., Selective Distribution by Luxury Goods Suppliers: A Response to Kinsella Et Al, European Competition Journal, Vol. 5, Issue 2, 2009, pp. 613-621

7. Buccirossi P, Vertical restraints on e-commerce and selective distribution, Journal of Competition Law \& Economics, Vol. 11, Issue 3,2015, pp. 747-773

8. Carlton D. W.; Chevalier J. A., Free-riding and Sales Strategies for the Internet, The Journal of Industrial Economics, Vol. XLIX, No. 4, 2001, pp. 441-461

9. Colangelo G.; Torti V., Selective distribution and online marketplace restrictions under $E U$ competition rules after Coty Prestige, European Competition Journal, Vol. 14, No 1, 2018, pp. $81-109$

156 Case C-323/09 Interflora Inc. and Interflora British Unit v Marks \& Spencer plc and Flowers Direct Online Ltd [2011] EU:C:2011:604 
10. Colomo P.I.; De Stefano G., The Challenge of Digital Markets: First, Let Us Not Forget the Lessons Learnt Over the Years, Journal of European Competition Law \& Practice, Vol. 9, Issue 8, 1 2018, pp 485-486

11. Eberhardt A., Why the discriminatory application of criteria in selective distribution systems is block exempted under Regulation 330/2010, European Competition Journal, Vol. 11, Issue 1, 2015, pp. 168-192

12. Fort A., Règles et pratiques communautaires en matière de distribution sélective des produits de luxe dans l'Union européenne, Observateur de Bruxelles, No. 28, 1998. pp. 18-20

13. Hoffmann F., Restrictions on Selective Distribution Systems on the Internet, CPI Antitrust Chronicle, October (2), 2014, pp. 1-9

14. Kato T.; Tsuda K., A Management Method of the Corporate Brand Image Based on Customers' Perception, Procedia Computer Science, Vol. 126, 2018, pp. 1368-1377

15. Kinsella Obe S.; Melin H.; Schropp S., Comments on the CRA Paper Entitled "An Economic Analysis of the Use of Selective Distribution by Luxury Goods Suppliers", European Competition Journal, Vol. 5, Issue 1, 2009, pp. 227-260

16. Koll O.; von Wallpach S., One brand perception? Or many?, Journal of Product \& Brand Management, Vol. 18, Number 5, 2009, pp. 338-345

17. Kunda I.; Butorac Malnar V., Internet Distribution of Luxury Products: Is There a Deluxe Version of EU Competition Law?, Zbornik Pravnog fakulteta Sveučilišta u Rijeci, Vol. 39, br. 4 Posebni broj, 2018, pp. 1751-1774

18. Monti G., Restraints on Selective Distribution Agreements, World Competition, Vol. 36, No. 4, 2013, pp. 489-512

19. Pruzhansky V., Luxury goods, vertical restraints and internet sales, European Journal of Law and Economics, Vol. 38, Issue 2, 2014, pp. 227-246

20. Reisinger M., Asics vs Coty: Competitive effects of selective distribution systems in light of diverging court decisions, CPI's Europe Column, 2018, pp. 1-5

21. Romano V. C., ECJ Ruling on the Prohibition of On-line Sales in Selective Distribution Networks, Journal of European Competition Law \& Practice, Vol. 3, Number 4, 2012, pp. 345-347

22. Schmidt-Kessen M. J., Selective Distribution Systems in EU Competition and EU Trademark Law, Journal of European Competition Law \& Practice, Vol. 9, No. 5, 2018, pp. 304-316

23. Tuytschaever F.; Wijckmans F., Vertical Agreements in EU Competition Law (3rd Edition), Oxford Competition Law, Oxford, 2018

24. Vogel, L.; Vogel, J., Traité de droit économique : Tome 2 - Droit de la distribution, Bruylant, Bruxelles, 2017

25. Waelbroeck D.; Davie Z., Coty, Clarifying Competition Law in the Wake of Pierre Fabre, Journal of European Competition Law \& Practice, Vol. 9, No. 7, 2018, pp 431-442

26. Wijckmans F., Coty Germany GmbH v Parfümerie Akzente GmbH: Possibility in Selective Distribution System to Ban Sales via Third-Party Platforms, Journal of European Competition Law \& Practice, Vol. 9, No. 6, 2018, pp. 372-375

27. Winter R. A., Pierre Fabre, Coty and Restrictions on Internet Sales: An Economist's Perspective, Journal of European Competition Law \& Practice, Vol. 9, No. 3, 2018, pp. 183-187 
28. Witt A. C., Restrictions on the use of third-party platforms in selective distribution agreements for luxury goods, European Competition Journal, Vol. 12, No. 2-3, 2016, pp. 435-461

29. Zelger B., Restrictions of online sales and vertical agreements: Bundeskartellamt vs. Commission? Why Coty and Asics are compatible, European Competition Journal, Vol.14, No. 2-3, 2018, pp. $445-461$

\section{COURT OF JUSTICE OF THE EUROPEAN UNION}

1. Case 56/65 Société Technique Minière [1966] EU:C:1966:38

2. Joined cases 56/64 and 58/64 Consten and Grundig $v$ Commission [1966] EU:C:1966:41

3. Case 26-76 Metro SB-Großmärkte GmbH \& Co. KG v Commission of the European Communities [1977] EU:C:1977:167

4. Joined cases 209 to 215 and 218/78 Heintz van Landewyck SARL and Others $v$ Commission of the European Communities [1980] EU:C:1980:248

5. Case 31/80 NVL'Oréal and SA L'Oréal v PVBA “De Nieuwe AMCK” [1980] EU:C:1980:289

6. Case 210/81 Oswald Schmidt, trading as Demo-Studio Schmidt, $v$ Commission of the European Communities [1983] EU:C:1983:277

7. Case 75/84 Metro SB-Großmärkte GmbH \& Co. KG v Commission of the European Communities [1986] EU:C:1986:399

8. Joined cases 25 and 26/84 Ford - Werke AG and Ford of Europe Inc. v Commission of the European Communities [1985] EU:C:1985:340

9. Case 107/82 Allgemeine Elektrizitäts-Gesellschaft AEG-Telefunken AGv Commission of the European Communities [1986] EU:C:1983:293

10. Case 31/85 ETA Fabriques d'Ébauches v SA DK Investment and others [1985] EU:C:1985:494

11. Case C-376/92 Metro SB-Großmärkte GmbH \& Co. KG v Cartier SA [1994] EU:C:1994:5

12. Case T-19/92 Groupement d'achat Edouard Leclerc $v$ Commission of the European Communities [1996] EU:T:1996:190

13. Case T-88/92 Groupement d'achat Edouard Leclerc $v$ Commission of the European Communities [1996] EU:T:1996:192

14. Case C-306/96 Javico [1998] EU:C:1998:173

15. Case C-16/03 Peak Holding AB v Axolin-Elinor AB (formerly Handelskompaniet Factory Outlet i Löddeköpinge AB) [2004] EU:C:2004:759

16. Case T-99/04 AC Treuhand v Commission [2008] EU:T:2008:256

17. Case C-59/08 Copad SA v Christian Dior couture SA, Vincent Gladel and Société industrielle lingerie (SIL) [2019] EU:C:2009:260

18. Joined cases C-236/08 to C-238/08 Google France SARL and Google Inc. v Louis Vuitton Malletier SA (C-236/08), Google France SARL v Viaticum SA and Luteciel SARL (C-237/08) and Google France SARL $v$ Centre national de recherche en relations humaines (CNRRH) SARL and Others (C-238/08) [2010] EU:C:2010:159

19. Case C-127/09 Coty Prestige Lancaster Group GmbH v Simex Trading AG [2010] EU:C:2010:313 
20. Case C-323/09 Interflora Inc. and Interflora British Unit v Marks \& Spencer plc and Flowers Direct Online Ltd [2011] EU:C:2011:604

21. Case C-439/09 Pierre Fabre Dermo-Cosmétique SAS v Président de l'Autorité de la concurrence and Ministre de l'Économie, de l'Industrie et de l'Emploi [2011] EU:C:2011:649

22. Case C-230/16 Coty Germany GmbH v Parfümerie Akzente GmbH [2017] EU:C:2017:941

23. Case C-230/16 Coty Germany GmbH v Parfümerie Akzente GmbH, Opinion of advocate General Wahl [2017] EU:C:2017:603

\section{EU LAW}

1. Treaty on the Functioning of the European Union, Consolidated version [2012] OJ C $326 / 47$

2. First Council Directive 89/104/EEC of 21 December 1988 to approximate the laws of the Member States relating to trade marks [1989] OJ L 40/1

3. Directive (EU) $2015 / 2436$ of the European Parliament and of the Council of 16 December 2015 to approximate the laws of the Member States relating to trade marks [2015] OJ L $336 / 1$

4. Commission Regulation (EC) No 2790/1999 of 22 December 1999 on the application of Article 81(3) of the Treaty to categories of vertical agreements and concerted practices [1999] OJ L 336/21

5. Commission Regulation (EU) No 330/2010 of 20 April 2010 on the application of Article 101(3) of the Treaty on the Functioning of the European Union to categories of vertical agreements and concerted practices [2010] OJ L 102/1

6. Guidelines on Vertical Restraints [2010] OJ C 130/1

\section{DECISIONS OF NATIONAL AUTHORITIES}

1. Bundesgerichtshof Beschluss KVZ 41/17 vom 12. Dezember 2017 in der Kartellverwaltungssache, DE:BGH:2017:121217BKVZ41.17.0, [http://juris.bundesgerichtshof.de/cgibin/rechtsprechung/document.py?Gericht=bgh\&Art=en \&Datum=Aktuell \&Sort=12288\& $\mathrm{nr}=80673 \&$ pos=25\&anz=515] Accessed 15.03.2019

2. Oberlandesgerichts Düsseldorf, Beschluss KVZ 41/17 vom 5. April 2017

3. Bundeskartellamt Beschluss B2-98/11 vom 26. August 2015 in dem Verwaltungsverfahren, [https://www.bundeskartellamt.de/SharedDocs/Entscheidung/DE/Entscheidungen/Kartellverbot/2015/B2-98-11.pdf?_blob=publicationFile\&v=3] Accessed 15.03.2019

4. Autorité de la concurrence, Décision n ${ }^{\circ} 18-\mathrm{D}-23$ du 24 octobre 2018 relative à des pratiques mises en œuvre dans le secteur de la distribution de matériel de motoculture, [http://www. autoritedelaconcurrence.fr/pdf/avis/18d23.pdf] Accessed 15.03.2019

\section{WEBSITE REFERENCES}

1. Arnold R.; Norman N.; Schmierer D., Resale Price Maintenance and Dual Distribution, Distribution and Franchising Committee: ABA Section of Antitrust Law, March 2016, [https:// 
www.cornerstone.com/Publications/Articles/Resale-Maintenance-and-Dual-Distribution] Accessed 15.03.2019

2. Bundeskartellamt, Case Summary: Unlawful restrictions of online sales of ASICS running shoes, [https://www.bundeskartellamt.de/SharedDocs/Entscheidung/EN/Fallberichte/Kartellverbot/2016/B2-98-11.pdf?_blob=publicationFile\&v=2] Accessed 15.03.2019

3. ColeM.,Asics'onlinesalesrestrictionsconfirmedasillegalby DuesseldorfHigherRegionalCourt, 8April 2017, [https://www.covbrands.com/2017/04/08/asics-online-sales-restrictions-confirmed-asillegal-by-duesseldorf-higher-regional-court/?_ga=2.242657154.1828475972.15534909552080505729.155349095] Accessed 15.03.2019

4. European Commission, Guidance on restrictions of competition "by object" for the purpose of defining which agreements may benefit from the De Minimis Notice, SWD(2014) 198 final, 25 June 2014, [http://ec.europa.eu/competition/antitrust/legislation/de_minimis_notice_annex.pdf] Accessed 15.03.2019

5. Report from the Commission to the Council and the European Parliament, Final report on the E-commerce Sector Inquiry, $\operatorname{COM(2017)~} 229$ final, 10 May 2017, [http://ec.europa. eu/competition/antitrust/sector_inquiry_final_report_en.pdf] Accessed 15.03.2019

6. Galarza A. F.; Dziadykiewicz E. L.; Perez A. G., Selective Distribution and e-Commerce: An overview of Selective Distribution and e-Commerce: An overview of EU and national case law, e-Competitions Antitrust Case Laws e-Bulletin, Issue: Selective distribution, N63958, 2014, pp. 1-13, [https://www.concurrences.com/en/bulletin/special-issues/selective-distribution-en/Selective-Distribution-and-e] Accessed 15.03.2019

7. Kuhn T.; Rust M., Who'd have guessed: Coty did not end the debate!, Lexology, 28 February 2019, [https://www.lexology.com/library/detail.aspx?g=9bd96871-695e-4d2f-9106-cf64a65c955a] Accessed 15.03.2019

8. Kunda I.; Materljan I., The EEA "Grey Market" in Trademarked Products: How Many Shades of Grey?, working paper presented at the INTA Annual Meeting, Trademark Scholarship Symposium 2017, [http://en.croatiamergers.eu/wp-content/uploads/2017/12/Kunda_Materljan-INTA_Working_Paper.pdf] Accessed 15.03.2019

9. Paseczki L.; Rózsavölgyi M., Trademarks and selective distribution: The protection of brand image and identity, ECTA, 2018, [http://www.ecta.org/uploads/events-documents/article_ PL_RM.pdf] Accessed 15.03.2019

10. Saez E., Aftermath of the STIHL case: The first President of the Paris Court of Appeal ordered a stay of execution regarding the four injunctions pronounced by the French Competition authority, 30 January 2019, [https://www.nomosparis.com/en/aftermath-of-the-stihl-case-thefirst-president-of-the-paris-court-of-appeal-ordered-a-stay-of-execution-regarding-the-fourinjunctions-pronounced-by-the-french-competition-authority-2/] Accessed 15.03.2019 